\title{
Student perceptions of the effectiveness of self-editing on their writing: towards a self-regulated approach
}

\author{
Gelareh Holbrook \\ Robert Gordon University, Aberdeen, UK \\ Victoria Park \\ Robert Gordon University, Aberdeen, UK
}

\begin{abstract}
A number of studies have highlighted the importance of teaching students to self-edit their work. Self-editing within higher education has been demonstrated to support students' academic writing skills. It also capitalises on lecturers' written corrective feedback on students' essay-based assignments making it more effective and meaningful. Utilising a collaborative approach between the Study Support and the School of Health Sciences at a UK-based university, this research evaluated the usefulness of a self-editing worksheet based on the perspectives of students, writing tutors, and the subject lecturer (staff) feedback. Students' perspectives were investigated by content analysing their responses provided in the reflection section of the self-editing worksheet. Qualitative analysis of staff feedback on pre- and post-edit writing was also evaluated. The results show that $65 \%$ of students' found the worksheet useful and the worksheet helped them make some positive changes to their essays. Evidence would suggest that this pedagogical model is effective in improving levels of academic writing. Implications and suggestions for effective teaching practice and future research are provided in this paper.
\end{abstract}

Keywords: self-editing; independent learning; self-regulated approach; academic writing.

\section{Introduction}

Academic writing is one of the cornerstones of university study as it is a crucial means of assessment with students being expected to write analytically and critically across all 
disciplines (QAA, 2016). Students' success is therefore partially dependent on their competence in writing (Borg and Deane, 2009; Gopee and Deane, 2013). Various types of written assessments, such as reports, reflective essays, and dissertations, are often assigned at universities in the UK, and students' performance is assessed based on criteria such as the format, language use, organisation of ideas, critical analysis, and incorporation of other sources (Gopee and Deane, 2013). A number of students, however, from undergraduate to postgraduate level, are reported to find conventions of academic writing challenging to understand or implement (Gopee and Deane, 2013; Rickard et al., 2009; Jackson, 2009; Borg and Deane, 2011). Several authors report the quality of students' writing in higher education is one of academics' major concerns (Borg and Dean, 2009; Dann, 2009; Lamb, 2009). This could be due to a number of reasons, namely, students' limited academic background; cultural differences (for non-native speakers, specifically); and generally limited writing experience.

Enhancing students' learning experiences is one of the UK universities' key strategic aims (QAA, 2016) highlighting the importance of providing support for students to overcome the barriers to their academic success. Gopee and Deane (2013) suggest that it is inadequate to expect students to pick up writing skills by trial and error. Consequently, a number of UK-based universities provide support for students' writing (Wingate, 2006) with support varying from one-to-one tuition, group sessions, short courses, or online self-study resources.

A number of studies have highlighted the importance of teaching students to self-edit, so that lecturers' corrective feedback on students' assignments become more effective and meaningful (Truscott, 1999, 2007; Ferris, 2004; Bruton, 2009). Self-editing has also been recognised as a self-regulated learning strategy. Through self-editing, students navigate their learning experience independently by learning to self-evaluate their writing through a systematic identification of their strengths and weaknesses (Gopee and Deane, 2013; Nicol and Macfarlane-Dick, 2006). However, these studies have only been undertaken with students for whom English is a second language (Khaki and Biria, 2016; Oshima and Hogue, 2006; Tsai and Lin, 2012; Diab, 2010).

In their recent study, Khaki and Biria (2016) investigated the effectiveness of self and peer-editing on 100 Iranian students undertaking a Teaching English as a Foreign Language (TEFL) programme. The category of errors in the self-editing exercise included 
punctuation, coherence and cohesion, as well as grammar and vocabulary. In this study, self-editing instructions resulted in significant improvements in postgraduate TEFL students' writing. The authors claimed that self-evaluation help students develop explicit awareness of their writing quality by looking at their work from the reader's perspective (Cho et al., 2010; Li and Hegelheimer, 2013).

Ferris (1995) also assessed the effectiveness of self-editing on non-native speakers' essays at university. Their self-editing worksheet was based on five categories of grammatical errors often notified in students' writing: noun errors; verb errors; punctuation and sentence errors; word form errors; and preposition errors. Ferris (1995) introduced patterns of frequent and stigmatising errors to students and provided a checklist to help them identify these errors in sample essays. This approach resulted in significant progress in students' quality of work, with fewer errors in each category over the course of a semester. These findings are supported by others (Truscott 1999, 2007; Ferris, 2004; and Li and Hegelheimer, 2013).

There is, however, limited research that evaluates the effectiveness of self-editing worksheets on the writing of English-speaking students studying in UK-based universities. In addition, previous research has rarely focused on student perspectives of the effectiveness of self-editing which would provide an in-sight into the appropriateness of such a worksheet. Consequently, this project set out to examine the following questions with a group of English speaking students:

1. Did the students believe that the worksheet supported them in evaluating and editing their work?

2. What were the students' perceived areas of improvement after using the selfediting worksheet?

3. How useful did the students find the worksheet?

\section{Methods}

The self-editing worksheet was being introduced with the aim of enhancing the students' academic writing skills. As with any enhancement, it is essential to evaluate the impact to establish if benefit is gained (QAA, 2016). Consequently, an action research approach was 
undertaken (Mitchell et al., 2009). As this was an enhancement activity, no ethical approval was required. The study protocol was, however, peer reviewed for error, bias and ethical issues prior to commencement.

This enhancement was piloted on a convenience sample of MSc Physiotherapy (preregistration) students. It was important to establish if students perceived the self-editing worksheet as beneficial as if they did not value the worksheet they are unlikely to use it. The self-editing worksheet required students to reflect on areas they needed to develop after using the prompts included in the worksheet (Appendix 2). Qualitative data from these reflections was gathered and analysed along with quantitative data from one Likert Scale question.

\section{Sample}

A convenience sample of 29 postgraduate MSc Physiotherapy (pre-registration) were invited to participate. Students were native English speakers from Ireland, North America, and Great Britain. They were in their first semester of study and preparing to submit their first summative assessment requiring academic writing at Master's level. From experience, these students frequently require feedback on their writing style and guidance to ensure that appropriate levels of grammar and critical discussion are utilised. Working at Master's level requires a significant level of autonomy and self-regulation in learning, which is why this group were selected as the pilot for the worksheet. Consent forms were signed by the participants prior to the research.

\section{Procedure}

All students were given the opportunity to undertake a formative piece of work to help them develop their writing skills to the required level. The task required students to write a 500-word essay. Once the essay was completed and submitted, the students were offered a workshop that introduced them to the self-editing worksheet. This workshop aimed to support students in the completion of their academic writing exercise, by helping them understand the conventions of academic writing, and the use of the self-editing worksheet. After this workshop, students were given 10 days to revise their essays using the selfediting worksheet and resubmit their work. Figure 1 gives an overview of the order of events. 
Students' essays were independently reviewed before and after using the self-editing worksheet by two writing tutors and their subject lecturer (henceforth staff) using a marking grid and a bank of comments that focused on the following criteria:

- Content and organisation

- Language use

- Punctuation

- Using other sources;

- Format (presentation, i.e. font, spacing, referencing style).

The second workshop was delivered after the data collection time period and aimed to provide students with some feedback on their results and further advice on areas to improve.

Figure 1. Overview of study.

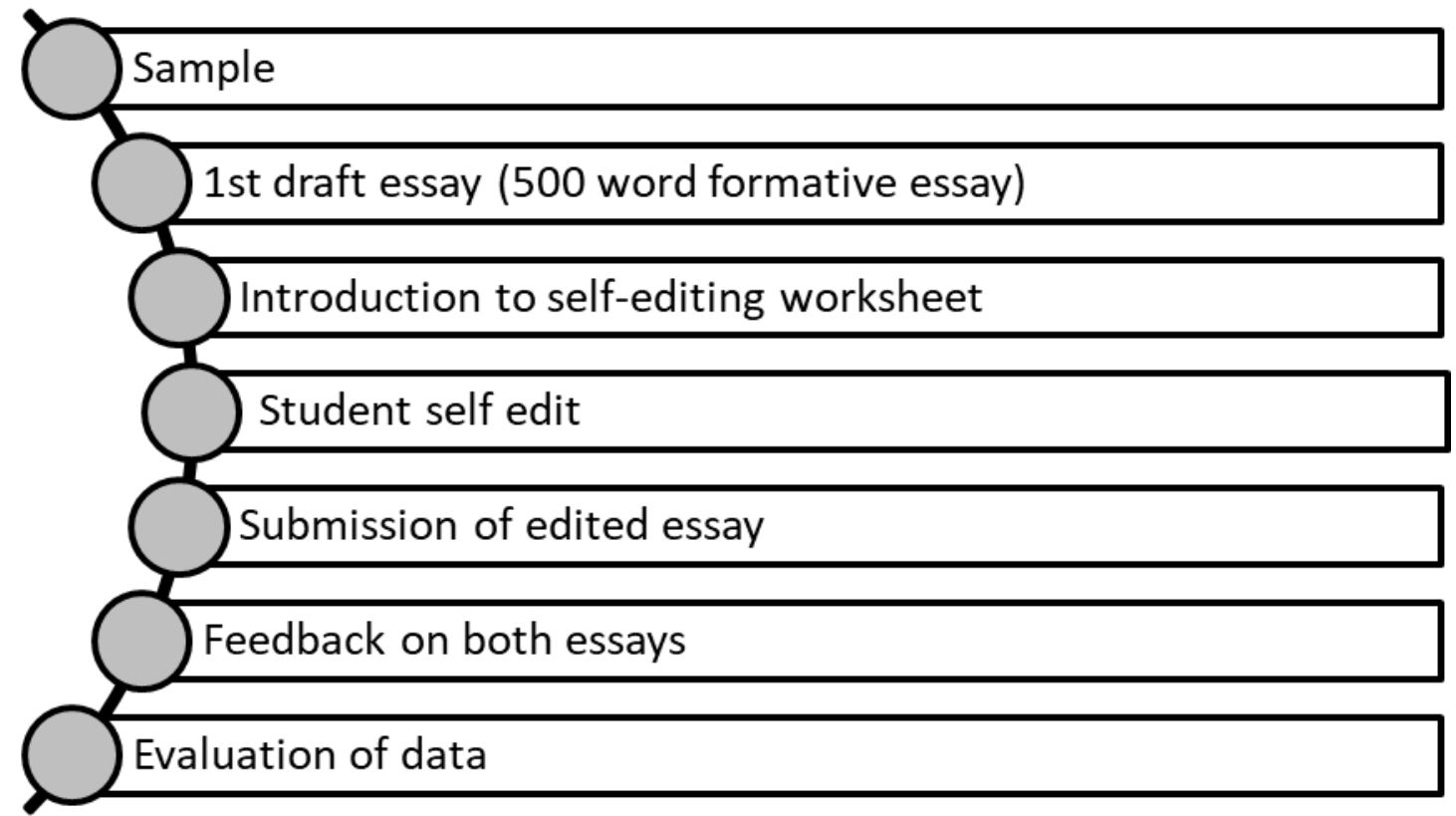

\section{Self-editing worksheet}

The self-editing worksheet (Appendix 1) consists of six sections: content and organisation; language use; punctuation; using other sources; format; and reflections. Each section contains a checklist, which aims to help students ensure that they have incorporated all the required components for each part of their essays, and they have adhered to the conventions of academic writing. The items in each checklist are followed by an example or instructions aiming to help students' self-study and develop their understanding of 
different writing skills independently (Appendix 2). The final section of the worksheet includes a reflection form.

\section{Data collection}

Data was collected from the reflective section of the self-editing worksheet that students completed. Students' comments were collated and categorised in a database, and the responses to the final Likert scale question were collected. For anonymity and ease of reference, each student was given a code: S1, S2, etc. (See Table 1).

Copies of the feedback provided by different staff was retained, consolidated and related to the student's reflections.

\section{Data analysis}

Students' responses to the questions were organised into common themes. Where appropriate, data was triangulated by cross checking the students' comments with that of the staff feedback. To do so, key words were identified in both the student and staff responses, resulting in the emergence of common themes (Table 1).

Quantitatively, the number of times students had mentioned changes in the areas of referencing, paragraphing, organisation, introduction, conclusion and grammar was identified and counted. This along with the results of the Likert scale question is reported in descriptive format.

\section{Results}

All 29 students submitted the first and second version of the formative essay. One student did not make changes to their second submission. Five students did not submit the selfediting worksheet. Consequently, full data was available for 23 students.

Data provided information about the student's perspectives of the usefulness of the selfediting worksheet, in addition to their perceived areas of improvement based on the weaknesses identified, improvements made, and strengths; this was triangulated with the staff feedback (Figure 2). 
Figure 2. Triangulation of data.

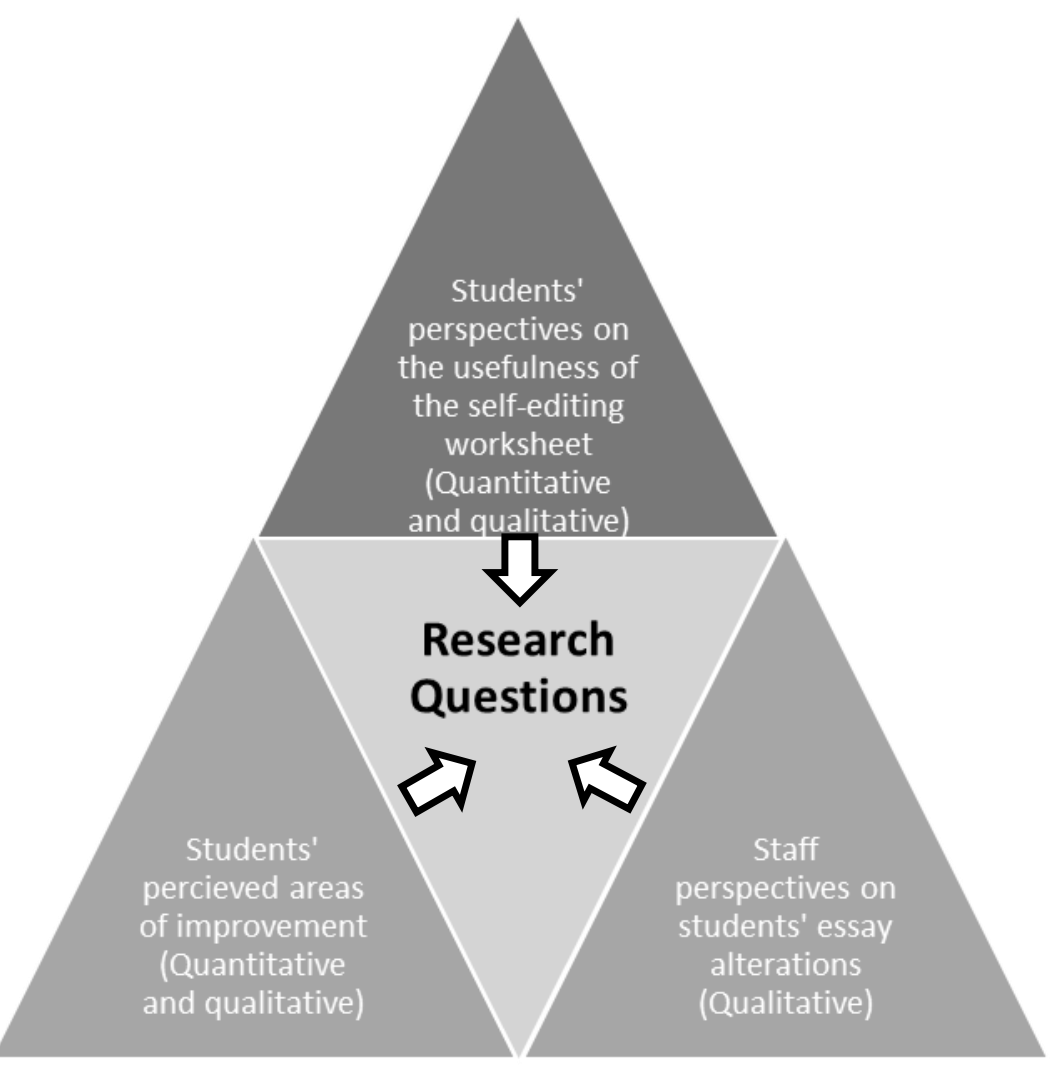

\section{Students' perceived areas of improvement}

In response to the question, 'what part(s) of your paper are you most proud of and why?', students used words and phrases including 'proud of', 'better', 'after using this worksheet I was able to', 'improve', 'improvement', and 'I was able to competently integrate the recommended guidelines for'. These words and phrases appeared with terms such as referencing (or sources, evidence, examples, support); paragraphing; organisation (or structure, layout, construct); introduction; conclusion; grammar; and punctuation, which frequently appeared in students' responses. These words were highlighted and the number of occurrences in all the responses is reported in Figure 3. 


\section{Figure 3. Students' Perceived Areas of Improvement.}

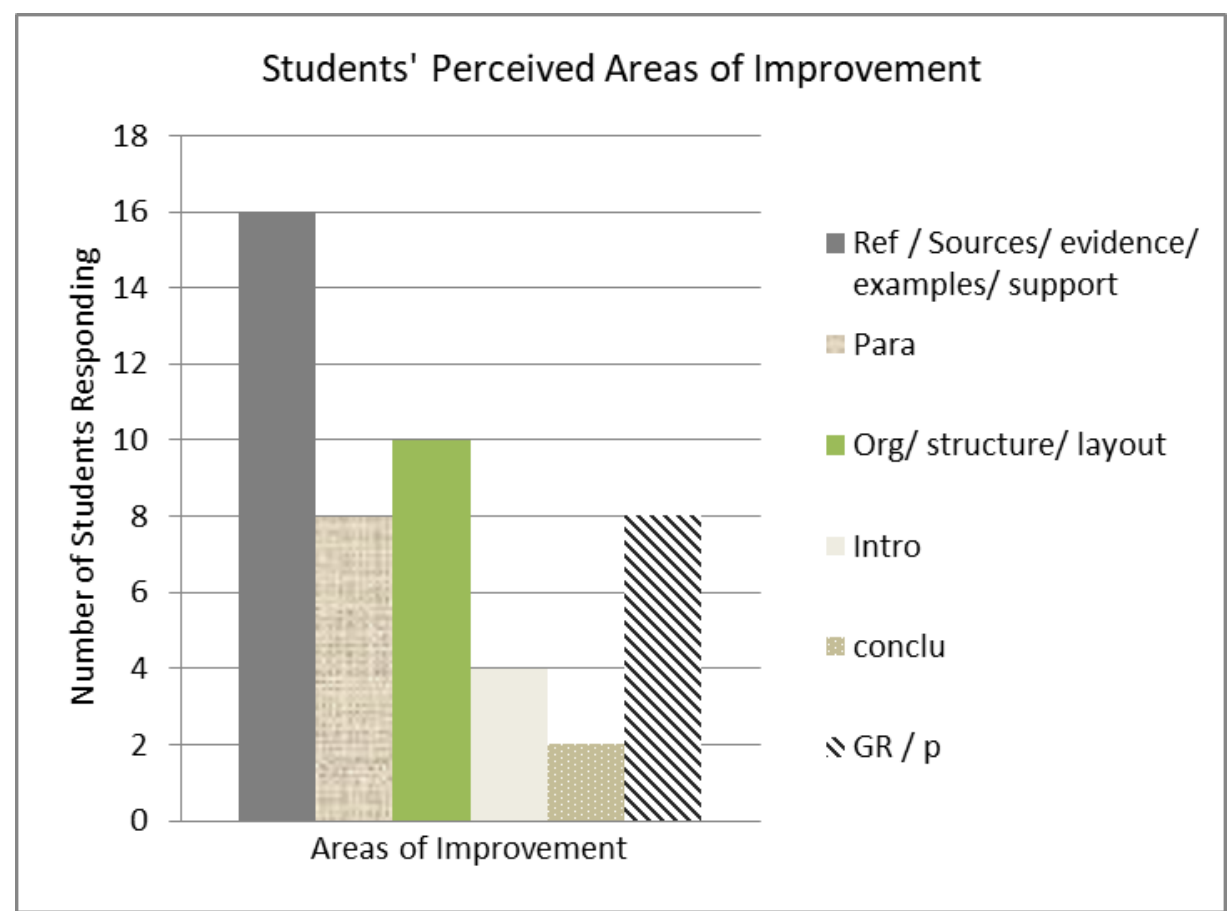

Abbreviations: Ref- Referencing, Para - Paragraphing, Org - Organisation, Intro - Introduction, Conclu - Conclusion, $\mathrm{GR} / \mathrm{p}$ - Grammar and punctuation.

Data in Table 1 suggests what amendments students believed they made to their essays as a consequence of using the self-editing worksheet. All 23 students who submitted their self-editing worksheet reported perceived benefit from it (this is shown in Table 1).

\section{Perceived areas for development}

Students' perceptions of their weaknesses in essay writing and their responses to 'What errors or weaknesses did the worksheet help you to identify?' are shown in Table 1. Phrases such as, 'needed to work further on'..., 'weakness', 'needed to focus'..., 'major concerns'..., 'error', and 'revision' directed the researchers to the students' perceived areas of weakness.

Staff feedback on the revised essays are also presented in Table 1. Adjectives, such as good, much better, improved, well, and clear, which signposted particular strengths in the student's work were used. These are underlined and illustrated in Table 1. Phrases in bold, well-structured, paragraphing, or references, followed or preceded by the positive adjectives, highlight the positive changes the staff agree that the students made in 
the revised version of their paper. The second column summarises the staff's suggestions for further improvement.

Apart from student 2, who did not make any amendments to her/ his essay, all other students believed they made positive changes to their work. This is verified by the staff's comments. 


\section{Table 1. Student perception and staff feedback.}

\section{Key}

\section{S= Student}

\section{Underlined comments $=$ perceived weaknesses}

Bold comments $=$ strengths/improvements

\begin{tabular}{|c|c|c|c|c|}
\hline & $\begin{array}{l}\text { Perceived } \\
\text { weaknesses } \\
\text { Student view }\end{array}$ & $\begin{array}{l}\text { Areas to } \\
\text { develop } \\
\text { from staff }\end{array}$ & $\begin{array}{l}\text { Perceived strengths } \\
\text { after editing } \\
\text { Student view }\end{array}$ & $\begin{array}{l}\text { Positive } \\
\text { changes } \\
\text { from staff }\end{array}$ \\
\hline S1 & $\begin{array}{l}\text { Finding evidence to } \\
\text { support/referencing correctly. } \\
\text { Avoiding combining too many } \\
\text { ideas and making sure the } \\
\text { reader is able to identify each } \\
\text { idea }\end{array}$ & $\begin{array}{l}\text { Need to } \\
\text { develop your } \\
\text { critical writing } \\
\text { further; limited } \\
\text { support for } \\
\text { your } \\
\text { discussion }\end{array}$ & $\begin{array}{l}\text { [l am proud of }] \\
\text { organisation and } \\
\text { transition between } \\
\text { paragraphs }\end{array}$ & $\begin{array}{l}\text { shows the beginning of } \\
\text { critical thinking }\end{array}$ \\
\hline S2 & $\begin{array}{l}\text { Grammar skill; Formatting and } \\
\text { referencing. }\end{array}$ & $\begin{array}{l}\text { Sources not used well to } \\
\text { support/refute your } \\
\text { discussion. Mainly } \\
\text { descriptive; include } \\
\text { additional sources to } \\
\text { support the points }\end{array}$ & $\begin{array}{l}\text { my content, valid points } \\
\text { about the health promotion } \\
\text { role a physiotherapist plays. }\end{array}$ & $\begin{array}{l}\text { Nothing additional [ ] on } \\
\text { second submission }\end{array}$ \\
\hline S3 & $\begin{array}{l}\text { My thesis statement [ ] needed } \\
\text { work [ ] One of my body } \\
\text { paragraphs didn't really back } \\
\text { up my thesis points; needed to } \\
\text { back up and use examples for } \\
\text { my topic sentences; Needed a } \\
\text { concluding remarks }\end{array}$ & $\begin{array}{l}\text { Needs to aim for more } \\
\text { balanced critique; needs } \\
\text { a few more sources to } \\
\text { support your discussion }\end{array}$ & $\begin{array}{l}\text { After editing, I think my } \\
\text { introduction flows better [ ]. } \\
\text { My body paragraphs support } \\
\text { my points/topic sentence } \\
\text { better. Reworked conclusion. }\end{array}$ & $\begin{array}{l}\text { Intro looks much better; } \\
\text { good coherence and } \\
\text { organisation; some } \\
\text { sources [ ] used } \\
\text { appropriately to support [ ] } \\
\text { discussion }\end{array}$ \\
\hline S4 & $\begin{array}{l}\text { Proper referencing and } \\
\text { punctuation }\end{array}$ & $\begin{array}{l}\text { Need more development } \\
\text { from a critical } \\
\text { perspective. need to } \\
\text { question evidence and } \\
\text { weigh arguments more }\end{array}$ & Construct & $\begin{array}{l}\text { The organisation and } \\
\text { structure has improved. }\end{array}$ \\
\hline S5 & $\begin{array}{l}\text { In my revisions, I focused on the } \\
\text { organization of my } \\
\text { introduction, main points and } \\
\text { conclusion, the flow of my } \\
\text { sentences, and the tenses used } \\
\text { throughout the paper. My major } \\
\text { concern was the } \\
\text { formatting/organization of my } \\
\text { main points. }\end{array}$ & $\begin{array}{l}\text { occasional sweeping } \\
\text { sentences; Critical } \\
\text { thinking and analysis is } \\
\text { an area that could be } \\
\text { developed further }\end{array}$ & $\begin{array}{l}\text { [This worksheet] helped to } \\
\text { identify how my paper should } \\
\text { be organized, I am most } \\
\text { proud of my introduction, } \\
\text { main points, and references } \\
\text { used. }\end{array}$ & $\begin{array}{l}\text { Formatting improved from } \\
\text { first draft. Improvements in } \\
\text { layout and referencing; a } \\
\text { good intro and [ ] } \\
\text { coherence. Irrelevant } \\
\text { parts removed. Aims of the } \\
\text { paragraphs are clearer. }\end{array}$ \\
\hline S6 & $\begin{array}{l}\text { lack of structure in conclusion, } \\
\text { The formatting/ referencing }\end{array}$ & $\begin{array}{l}\text { Critical evaluation is } \\
\text { lacking; avoid first person } \\
\text { forms }\end{array}$ & $\begin{array}{l}\text { after using this worksheet I } \\
\text { was able to organize the } \\
\text { paragraphs into topics }\end{array}$ & $\begin{array}{l}\text { has improved from the first } \\
\text { attempt with some restricting } \\
\text { of paragraphs }\end{array}$ \\
\hline
\end{tabular}




\begin{tabular}{|c|c|c|c|c|}
\hline S7 & $\begin{array}{l}\text { This worksheet helped me } \\
\text { identify my weaknesses with } \\
\text { developing concise conclusion } \\
\text { sentences for each paragraph. }\end{array}$ & $\begin{array}{l}\text { Beginning to consider } \\
\text { some critical evaluation } \\
\text { but this needs to be } \\
\text { developed. Utilise a wider } \\
\text { variety of literature; avoid } \\
\text { sweeping statements, }\end{array}$ & $\begin{array}{l}\text { The opening paragraph and } \\
\text { the closing paragraph are } \\
\text { really good }\end{array}$ & $\begin{array}{l}\text { A cohesive piece that flows } \\
\text { from introduction to } \\
\text { conclusion. }\end{array}$ \\
\hline S8 & $\begin{array}{l}\text { It helped identify weaknesses in } \\
\text { the organization of my essay, } \\
\text { specifically, what is required in } \\
\text { the introductory paragraph; } \\
\text { My biggest concern is my } \\
\text { grammar, [ ] and punctuation. } \\
\text { My secondary focus will be on } \\
\text { using more advanced } \\
\text { vocabulary }\end{array}$ & $\begin{array}{l}\text { Some counter } \\
\text { argument; try to develop } \\
\text { this further; avoid first } \\
\text { person forms. Some } \\
\text { changes [ ] have affected } \\
\text { the grammar and flow. }\end{array}$ & $\begin{array}{l}\text { I am most proud of my } \\
\text { introduction }\end{array}$ & $\begin{array}{l}\text { These are good points. You } \\
\text { begin to offer some counter } \\
\text { argument; a good range of } \\
\text { sentence structures }\end{array}$ \\
\hline S9 & $\begin{array}{l}\text { I feel like I need to concentrate } \\
\text { most on my comma use, and } \\
\text { ensuring I use proper structure. }\end{array}$ & $\begin{array}{l}\text { needs some work to build } \\
\text { on effective critical use } \\
\text { of the literature }\end{array}$ & $\begin{array}{l}\text { The worksheet helped me to } \\
\text { identify my wrongful use of } \\
\text { commas, my inadequate } \\
\text { structure and many other } \\
\text { aspects. I was most proud of } \\
\text { construction, as I feel my } \\
\text { formatting and structure } \\
\text { improved }\end{array}$ & $\begin{array}{l}\text { Refs updated and now } \\
\text { correctly formatted. A } \\
\text { coherent message; clear } \\
\text { introduction }\end{array}$ \\
\hline S10 & $\begin{array}{l}\text { Some errors with flow and } \\
\text { going off topic; have lots of } \\
\text { ideas but struggle to put them } \\
\text { down in a coherent manner. my } \\
\text { reference was not even close to } \\
\text { how it was supposed to be on } \\
\text { my first submission. }\end{array}$ & $\begin{array}{l}\text { need to work more } \\
\text { effectively to provide a } \\
\text { more balanced opinion; } \\
\text { demonstrate some } \\
\text { analysis, though this } \\
\text { could be further } \\
\text { developed; }\end{array}$ & $\begin{array}{l}\text { I am most proud of the } \\
\text { changes I made from my first } \\
\text { version to my second. }\end{array}$ & $\begin{array}{l}\text { Intro improved. Paragraph } \\
\text { structure, body para } 2 \\
\text { specifically, improved: a } \\
\text { better topic sentence and } \\
\text { concluding remarks; focus } \\
\text { is clear. Some improvement } \\
\text { in sentence structure }\end{array}$ \\
\hline S11 & $\begin{array}{l}\text { Grammar, lay-out, appropriate } \\
\text { use of sources and referencing. }\end{array}$ & No negative comments & $\begin{array}{l}\text { [proud of ] the structure and } \\
\text { organization of the paper. } \\
\text { The use of a wide variety of } \\
\text { sources and research. }\end{array}$ & $\begin{array}{l}\text { Utilised a wide variety of } \\
\text { literature; well structured. } \\
\text { Small changes made have } \\
\text { helped with the flow. }\end{array}$ \\
\hline S12 & $\begin{array}{l}\text { my major concern is repeating } \\
\text { myself }\end{array}$ & $\begin{array}{l}\text { critical writing style } \\
\text { requires some work so } \\
\text { that you provided a } \\
\text { balanced opinion; } \\
\text { Reporting verbs should } \\
\text { be used }\end{array}$ & $\begin{array}{l}\text { [this worksheet] helped create } \\
\text { a skeleton to work off when } \\
\text { constructing a paragraph. } \\
\text { The body as i feel i could get } \\
\text { my point across clearly }\end{array}$ & $\begin{array}{l}\text { have used the_worksheet } \\
\text { well to help you identify long } \\
\text { sentences and some } \\
\text { grammatical issues. This } \\
\text { second version reads better } \\
\text { than the first. Clear and well- } \\
\text { structured Introduction }\end{array}$ \\
\hline $\mathbf{S 1 3}$ & $\begin{array}{l}\text { Concern: trying to fit more } \\
\text { sources into the body of the } \\
\text { text to compare against each } \\
\text { other; found it difficult to } \\
\text { comment and make suggestions } \\
\text { at the end of paragraphs }\end{array}$ & $\begin{array}{l}\text { Lacking detail! Ideas } \\
\text { could be more fully } \\
\text { developed; make use of } \\
\text { more sources, use a } \\
\text { wider range of sentence } \\
\text { structures and linking } \\
\text { words. }\end{array}$ & $\begin{array}{l}\text { I think the introduction was } \\
\text { quite strong and the use of } \\
\text { the case study was good to } \\
\text { back up evidence. }\end{array}$ & $\begin{array}{l}\text { Improve[d] this from original } \\
\text { draft; now the introduction } \\
\text { gives a clearer outline; } \\
\text { have used the self-editing } \\
\text { worksheet well }\end{array}$ \\
\hline $\mathbf{S 1 4}$ & $\begin{array}{l}\text { major concern is that I was } \\
\text { unable to stay within the word }\end{array}$ & $\begin{array}{l}\text { need to build on using } \\
\text { that literature in a more }\end{array}$ & $\begin{array}{l}\text { thought the 2nd draft was } \\
100 x \text { better than the 1st }\end{array}$ & $\begin{array}{l}\text { better than the first attempt. } \\
\text { Better use of references; }\end{array}$ \\
\hline
\end{tabular}




\begin{tabular}{|c|c|c|c|c|}
\hline & count & $\begin{array}{l}\text { critical way; use } \\
\text { appropriate reporting } \\
\text { verbs; avoid informal } \\
\text { language }\end{array}$ & & $\begin{array}{l}\text { have corrected the } \\
\text { formatting issues in the first } \\
\text { draft. }\end{array}$ \\
\hline S15 & $\begin{array}{l}\text { worksheet helped to identify } \\
\text { places where I was using words } \\
\text { that were not supporting the } \\
\text { topic of my paper. }\end{array}$ & $\begin{array}{l}\text { Some sections(paragraph } \\
\text { 3) are more descriptive } \\
\text { and you should work on } \\
\text { building a more } \\
\text { balanced and critical } \\
\text { argument on the whole }\end{array}$ & $\begin{array}{l}\text { The conclusion and the } \\
\text { second paragraph of the } \\
\text { body }\end{array}$ & $\begin{array}{l}\text { worked on the structure;. } \\
\text { improvements in the } \\
\text { structure of introduction } \\
\text { and sentences; utilised the } \\
\text { self-editing worksheet } \\
\text { effectively; }\end{array}$ \\
\hline S16 & $\begin{array}{l}\text { Concern: finding sources and } \\
\text { being able to critically think }\end{array}$ & $\begin{array}{l}\text { You do still need to work } \\
\text { on a more balanced } \\
\text { approach to this that } \\
\text { offers different } \\
\text { perspectives on the topic; } \\
\text { do not overuse quotes; } \\
\text { make use of a variety of } \\
\text { reporting verbs. }\end{array}$ & $\begin{array}{l}\text { Intro and Conclusion and my } \\
\text { 3rd body paragraph }\end{array}$ & $\begin{array}{l}\text { Some improvements made } \\
\text { to the first draft. Some } \\
\text { additions to sources. }\end{array}$ \\
\hline S17 & $\begin{array}{l}\text { My conclusion was weak, Also, I } \\
\text { had a couple of sentences that } \\
\text { needed adjustment because } \\
\text { they made the flow of my paper } \\
\text { choppy and inconsistent } \\
\text { I would like to focus on [ ] using } \\
\text { references appropriately and } \\
\text { effectively. }\end{array}$ & $\begin{array}{l}\text { doesn't really answer the } \\
\text { question appropriately; } \\
\text { not really a critical } \\
\text { evaluation }\end{array}$ & $\begin{array}{l}\text { I am most proud of the body } \\
\text { of my paper. I feel as If I bring } \\
\text { my points together, and } \\
\text { provide good examples to } \\
\text { support my points. }\end{array}$ & $\begin{array}{l}\text { good examples of different } \\
\text { exercise interventions. } \\
\text { Ideas well supported; link } \\
\text { together your themes quite } \\
\text { well from introduction to } \\
\text { conclusion; some positive } \\
\text { changes made to the } \\
\text { structure following self- } \\
\text { editing. }\end{array}$ \\
\hline S18 & $\begin{array}{l}\text { This worksheet helped me } \\
\text { identify weaknesses in the } \\
\text { structure of my paper as well as } \\
\text { choppiness; I will focus my } \\
\text { revision on the cohesion of } \\
\text { thought within the paper as well } \\
\text { as eliminating any unnecessary } \\
\text { or unrelated content }\end{array}$ & $\begin{array}{l}\text { Build on your critical } \\
\text { evaluation. }\end{array}$ & $\begin{array}{l}\text { I am most proud of my } \\
\text { conclusion }\end{array}$ & $\begin{array}{l}\text { A relatively cohesive piece; } \\
\text { the changes made aide in } \\
\text { the flow. The introduction } \\
\text { and conclusion offer clear } \\
\text { indication as to what is } \\
\text { covered and evaluated; } \\
\text { used the worksheet quite } \\
\text { effectively to make positive } \\
\text { changes to your work. }\end{array}$ \\
\hline S19 & $\begin{array}{l}\text { Concern: flow and connection } \\
\text { between sentences and } \\
\text { paragraphs; Overall structure }\end{array}$ & $\begin{array}{l}\text { just make sure you don't } \\
\text { go off track and keep } \\
\text { focused; some sections } \\
\text { become somewhat } \\
\text { descriptive; Make use of } \\
\text { precise reporting verbs }\end{array}$ & $\begin{array}{l}\text { Body paragraphs. I believe } \\
\text { that I was able to competently } \\
\text { integrate the recommended } \\
\text { guidelines for paragraph } \\
\text { structure }\end{array}$ & $\begin{array}{l}\text { presentation and cohesion } \\
\text { have improved significantly } \\
\text { from your first draft; good } \\
\text { use of subheadings; } \\
\text { improvements in formatting } \\
\text { of refs; used the self-editing } \\
\text { worksheet to make some } \\
\text { effective changes. }\end{array}$ \\
\hline $\mathbf{S 2 0}$ & $\begin{array}{l}\text { This worksheet helped me to } \\
\text { identify: } \\
\text {-Incorrect verb tenses I used } \\
\text {-Incorrect formatting } \\
\text {-In text citation error } \\
\text { need to concentrate the most on } \\
\text { the formatting of my paper }\end{array}$ & $\begin{array}{l}\text { there is an over reliance } \\
\text { on some sources; more } \\
\text { work is required on using } \\
\text { your literature critically }\end{array}$ & $\begin{array}{l}\text { I think the flow of my paper } \\
\text { is relatively decent }\end{array}$ & $\begin{array}{l}\text { Sources well presented. } \\
\text { Improved formatting from } \\
\text { the original draft; added } \\
\text { better linking sentences. } \\
\text { Well-org; Clearer thesis }\end{array}$ \\
\hline
\end{tabular}




\begin{tabular}{|c|c|c|c|c|}
\hline S21 & $\begin{array}{l}\text { Concerns: avoiding run-on } \\
\text { sentences. Making sure each } \\
\text { paragraph is complete and } \\
\text { statements are supported. } \\
\text { Making sure I am using the } \\
\text { Harvard referencing correctly }\end{array}$ & $\begin{array}{l}\text { Good number of sources } \\
\text { are used, but views not } \\
\text { compared or evaluated. }\end{array}$ & $\begin{array}{l}\text { [This worksheet helped me] } \\
\text { make sure my paragraph } \\
\text { structure is complete, and } \\
\text { fully supported with two } \\
\text { different evidence sources. } \\
\text { communication of my point } \\
\text { through concise sentences, } \\
\text { while providing sufficient } \\
\text { evidence }\end{array}$ & $\begin{array}{l}\text { Good number of sources } \\
\text { are used, } \\
\text { Good Intro. Relevant thesis } \\
\text { statement Generally well- } \\
\text { structured. Coherent in } \\
\text { general }\end{array}$ \\
\hline S22 & $\begin{array}{l}\text { Weakness: content and layout } \\
\text { of each section; critical } \\
\text { analysis. Comparison of } \\
\text { sources not just using one } \\
\text { source to back a point }\end{array}$ & $\begin{array}{l}\text { Paragraph } 4 \text { offers some } \\
\text { critical discussion. The } \\
\text { other sections are less } \\
\text { well written and } \\
\text { somewhat descriptive. }\end{array}$ & $\begin{array}{l}\text { Introduction - most } \\
\text { improvement. }\end{array}$ & $\begin{array}{l}\text { You have worked on } \\
\text { providing better linking and } \\
\text { summarising statements } \\
\text { in your introduction and } \\
\text { conclusion. A great deal of } \\
\text { improvement in organising } \\
\text { ideas. }\end{array}$ \\
\hline $\mathbf{S 2 3}$ & $\begin{array}{l}\text { Paragraph structure; } \\
\text { organisation of ideas; and being } \\
\text { specific }\end{array}$ & $\begin{array}{l}\text { additional analysis } \\
\text { needed; errors in } \\
\text { reference format; } \\
\text { informal language and } \\
1^{\text {st }} \text { person need to be } \\
\text { avoided }\end{array}$ & No positive comments & Good Intro and Conclusion \\
\hline
\end{tabular}

\section{The usefulness of the self-editing worksheet}

Twenty of the 23 students completed the Likert question 'usefulness of the worksheet'. On a scale of 1 to $5,65 \%$ of the participants (13/20) rated the usefulness as 4 or 5 . Only one student rated the usefulness as 2 .

Students' reflections contained key phrases, such as 'this worksheet helped me', or 'was helpful for', indicating that students' interpreted the Likert scale as 1 not useful and 5 very useful.

The following qualitative data indicate how students benefited from the worksheet:

1. It helped to identify how my paper should be organized. (S5)

2. This worksheet helped me to identify my weaknesses with developing concise conclusion sentences for each paragraph. (S7)

3. The worksheet helped me to identify my wrongful use of commas, my inadequate structure and many other issues. (S9)

4. It helped create a skeleton to work off when constructing a paragraph. (S12) 
5. I think the worksheet helped to identify places where I was using words that were not supporting the topic of my paper. The check points are helpful for staying on track and determining what should be included in each section. (S15)

6. This worksheet helped me to identify, incorrect verb tenses I used, incorrect formatting, and in text citation error. (S20)

Few students' comments suggested some possible shortcomings in the design of the worksheet based on their perspectives:

1. Worksheet could be more effective with more examples. (S8)

2. I am not knowledgeable enough. [Referring to the checklist for Language use] (S1)

3. This was helpful but can be overwhelming. (S15)

\section{Discussion and implications}

This data is promising and indicates students found the self-editing worksheet useful, and they perceived that generally they made positive changes to their work as a consequence of using the worksheet. This was corroborated by the staff feedback. These findings are in line with those from previous research with those for whom English is a second language (Truscott, 1999, 2007; Ferris, 2004; Li and Hegelheimer, 2013).

While some students made major amendments to their work, others made only minor changes. Only one student made no changes at all. The subject lecturer indicated the majority of students made positive changes in their second submission. Also, the content analysis (Bryman, 2009) showed how each student identified their own specific weaknesses and used the worksheet to address those weaknesses to make improvements. None of the work evaluated was negatively impacted upon by the use of the worksheet.

Most studies on self-editing exercises in higher education have focused on the effectiveness of the approach for non-native speakers and in terms of grammar and punctuation (Ferris, 2004; Li and Hegelheimer, 2013). In addition to demonstrating these benefits, this study suggests the worksheet also facilitated students to develop the 
structure of their academic writing (i.e. overall structure and paragraphing) and the incorporation of literature. A significant number of students referred to the corrections they made in terms of referencing, or use of other sources in their work; also recognised in the staff comments. This suggests that the self-editing worksheet helped students to identify where and how they needed to develop their use of supporting literature.

While enhancing the use of referencing, staff's comments in areas for further improvements involve the word 'criticality' in relation to most students' work (Table 1.) This suggests the self-editing worksheet may require enhancement to help students reach their potential in terms of critical writing. Currently, the prompts in the worksheet refer to structural and grammatical/punctuation issues in relation to writing. They do not encourage students to consider their content and critical writing skills. This is perhaps less important at lower undergraduate level but remains a key issue in terms of honours level and postgraduate work (SQA, 2015). In this study, staff feedback encouraged students to consider the criticality of their writing but the impact of this was not evaluated. Further investigation would be valuable to determine if this is the most appropriate method for helping students develop these critical writing and thinking skills.

The student comments indicate that the self-editing worksheet was useful at helping them identify where they needed to develop their academic writing skills. Overall, they were positive that the worksheet was beneficial. However, although the negative comments were limited, they could inform the development of the self-editing worksheet. It may be helpful to have direction in the worksheet to more detailed learning resources relating to the aspect of writing the student is finding challenging, thus providing further 'scaffolding' to enable writing development (Vygotsky, 1987). This would enable them to consolidate and develop their understanding of that area before then modifying their work.

Results suggest the number of prompts may be overwhelming for some students. It may be appropriate to break the worksheet into several separate worksheets that could be introduced to students at the start of their undergraduate degrees. Consequently, by the time they reach postgraduate study, these basic structural issues should no longer be problematic, enabling the focus to shift to critical thinking and writing aspects. For other students, it may be that they need a more supportive mechanism of meeting with a tutor to discuss areas requiring development. This may be influenced by how the student has been taught in the past, their level of autonomy or their learning style. However, at 
postgraduate level, students should be autonomous and reflection is required as a graduate skill (QAA, 2009). Consequently, the use of a self-editing worksheet encourages the appropriate level of graduate skills.

\section{Limitations and further research}

What has not been established is whether students have transferred learning from this piece of work to subsequent written assessments. It would be of benefit to assess the quality of the changes applied from the first to second formative submissions of this work and then to evaluate the quality of the summative assessment that these students would complete.

This study was carried out with a limited number of students from several countries and therefore replication of the study with a wider population is required to enable generalisability of the results. Further investigation into whether the worksheet assists those from the USA/Canada to adapt to British writing conventions would be valuable. This self-regulated approach has potential to be further developed and used by a wider number of students at university, while the theme of independent learning is at the core of all UK-based universities' pedagogical approaches (QAA, 2016). Introducing the worksheet to students in year one of their undergraduate studies may therefore be beneficial and worthy of investigation.

Methods of data collection in this study were limited as they focused on collecting data only from the worksheet and student work. They could not provide the rich data that ethnographic methods such as interviews or focus groups could have provided about student perspectives of the intervention. However, the informal nature of the data collection may have enabled students to be more honest about their actual use of the worksheet.

Future studies should focus on marking students' essays before and after the intervention to assess whether the use of a self-editing worksheet impacts on students' grades due to improvements in their academic writing. It would also be of use to investigate if ongoing use of the worksheet provides additional and sustained benefits. Furthermore, future research could be strengthened by means of language-based methods of analysis, such as discourse analysis or text analysis (Ritchie and Lewis, 2014), to closely assess the 
changes made in students' sentence structure, paragraphing, punctuation, etc. before and after self-editing. Effective approaches have been suggested by Borg and Deane (2011) in this regard.

\section{Conclusions}

Despite its limitations, this study has shown that the students had positive perceptions of a self-editing approach. It helped them not only to evaluate and address their weaknesses in writing independently, but also to identify their strengths. These preliminary results suggest improvements to the overall student learning experience. Moreover, this study extended the results of previous studies by confirming the usefulness of this self-regulated learning strategy for native English speaking students. However, further research aiming to develop this worksheet to support students' analytical writing skills more effectively is required.

\section{Acknowledgements}

With thanks to the MSc Physiotherapy students for participating in this study and to Fiona Roberts from the School of Health Sciences for her efforts in the peer review and editing of the paper. We extend our thanks to the Academic Development team at DELTA, Dr Rachel Macgregor, Lynne Loveday and Irina Radu, whose help and advice facilitated the completion of this project.

\section{References}

Borg, E. and Deane, M. (2009) Interim report on individualised writing tutorials at Coventry University's Centre for Academic Writing (CAW). Coventry University: unpublished document.

Borg, E. and Deane, M. (2011) 'Measuring the outcomes of individualised writing instruction: a multi-layered approach to capturing changes in students' texts', Teaching in Higher Education, 16(3), pp. 319-331. 
Bruton, A. (2009) 'Designing research into the effects of grammar correction in L2 writing: not so straightforward', Journal of Second Language Writing, 18(2), pp. 136-140.

Bryman, A. (2009) Social research methods. Oxford: Oxford University Press.

Cho, K., Cho, M.H. and Hacker, D.J. (2010) 'Self-monitoring support in learning to write', Interactive Learning Environments, 18(2), pp. 101-113.

Dann, C. (2009) 'The never-ending sentence', The Times Higher Education, 2 July, p.19.

Diab, N.M. (2010) 'Effects of peer-versus self-editing on students' revision of language errors in revised drafts', System, 38(1), pp. 85-95.

Ferris, D.R. (1995) 'Teaching students to self-edit', TESOL Journal, 4(4), pp. 18-22

Ferris, D.R. (2004) 'The 'grammar correction' debate in L2 writing: where are we, and where do we go from here? (and what do we do in the meantime...?)', Journal of second language writing, 13(1), pp. 49-62.

Gopee, N. and Deane, M. (2013) 'Strategies for successful academic writing - Institutional and non-institutional support for students', Nurse Education Today, 33(12), pp. 1624-1631.

Jackson, D. (2009) 'Mentored residential writing retreats: a leadership strategy to develop skills and generate outcomes in writing for publication', Nurse Education Today, 29(1), pp. 9-15.

Khaki, M. and Biria, R. (2016) 'Effects of self-and peer-editing on Iranian TEFL postgraduate students' L2 writing', Journal of Applied Linguistics and Language Research, 3(1), pp. 155-166.

Lamb, B.C. (2009) 'British undergraduates make three times as many errors in English as do ones from overseas', Quest, 103, pp. 12-18. 
Li, Z. and Hegelheimer, V. (2013) 'Mobile-assisted grammar exercises: effects on selfediting in L2 writing', Language Learning \& Technology, 17(3), pp. 135-156.

Mitchell, S.M., Reilly, R.C. and Logue, M.E. (2009) 'Benefits of a collaborative action research for the beginning teacher', Teaching and Teacher Education, 25(2), pp. 344-349.

Nicol, D. and Macfarlane-Dick, D. (2006) 'Formative assessment and self-regulated learning: a model and seven principles of good feedback practice', Studies in Higher Education, 31(2), pp. 199-218.

Oshima, A. and Hogue, A. (2006) Writing Academic English. $4^{\text {th }}$ Edition (Longman Academic Writing Series): Level 4. US: Pearson Education.

QAA (2009) Enhancement themes. Available at:

http://www.enhancementthemes.ac.uk/docs/publications/research-teachinglinkages-enhancing-graduate-attributes-overview.pdf\#page=18 (Accessed: 10 December 2016).

QAA (2016) Safeguarding standards and improving the quality of UK higher education. Available at:

http://www.qaa.ac.uk/about-us/scotland/development-and-enhancement (Accessed: 26 April 2016).

Rickard, C.M., McGrail, M.R., Jones, R., O'Meara, P., Robinson, A., Burley, M., and RayBarruel G. (2009) 'Supporting academic publication: evaluation of a writing course combined with writers' support group', Nurse Education Today, 29(5), pp. 516-521.

Ritchie, J. and Lewis, J. (2014) Qualitative research practice: a guide for social science students and researchers. $2^{\text {nd }}$ edn. Los Angeles: Sage.

Scottish Qualifications Agency (SQA) (2015) The Scottish Credit and Qualifications Framework (SCQF). Available at: http://scaf.org.uk/wpcontent/uploads/2014/03/SCQF-Level-Descriptors-WEB-Aug-2015.pdf (Accessed: 26 April 2016). 
Truscott, J. (1999) 'The case against grammar correction in L2 writing classes: a response to Ferris', Journal of Second Language Writing, 8(2), pp. 111-122.

Truscott, J. (2007) 'The effect of error correction on learners' ability to write accurately', Journal of second language Writing, 16(4), pp. 255-272.

Tsai, Y.R. and Lin, C.F. (2012) 'Investigating the effects of applying monitoring strategy in EFL Writing Instruction', International Journal of Business and Social Science, 3(13), pp. 205-216.

Vygotsky, L. (1987) Mind in society: the development of higher psychological processes. Cambridge: Harvard University Press.

Wingate, U. (2006) 'Doing away with 'study skills”, Teaching in Higher Education, 11(4), pp. 457-469.

\section{Author details}

Gelareh Holbrook holds a PhD in Education and is a Writing and Study Skills tutor/English for Academic Purposes Lecturer at the Department for the Enhancement of Learning, Teaching and Access (DELTA) at Robert Gordon University, Aberdeen.

Victoria Park holds an MSc in Pain Management and BSc in Physiotherapy. Victoria is a Lecturer in Physiotherapy in the School of Health Sciences at Robert Gordon University, Aberdeen. 
Appendix 1. Overview of self-editing worksheet.

\begin{tabular}{|c|c|c|c|}
\hline & Sections & Subsections & Content \\
\hline Section 1 & $\begin{array}{l}\text { Content and } \\
\text { organisation }\end{array}$ & $\begin{array}{l}\text { Introduction } \\
\text { Body } \\
\text { Conclusions }\end{array}$ & \multirow{5}{*}{$\begin{array}{l}\text { Prompts } \\
\text { Examples } \\
\text { Self-evaluation of confidence } \\
\text { Comments or questions - free text } \\
\text { box }\end{array}$} \\
\hline Section 2 & Language & $\begin{array}{l}\text { Verbs } \\
\text { Sentence structure }\end{array}$ & \\
\hline Section 3 & Punctuation & $\begin{array}{l}\text { Commas } \\
\text { Semi-colons } \\
\text { Colons }\end{array}$ & \\
\hline Section 4 & $\begin{array}{l}\text { Using other } \\
\text { sources }\end{array}$ & & \\
\hline Section 5 & Format & & \\
\hline Section 6 & Reflections & & $\begin{array}{l}\text { What part of the paper are you most } \\
\text { proud of and why? } \\
\text { What areas of your writing will you } \\
\text { concentrate on the most in your } \\
\text { revision to improve? What is your } \\
\text { major concern? } \\
\text { What errors or weaknesses did the } \\
\text { worksheet help to identify? } \\
\text { On a scale of } 1-5 \text { how useful did } \\
\text { you find the worksheet? }\end{array}$ \\
\hline
\end{tabular}




\section{Appendix 2. Self-editing worksheet.}

\section{SELF EDITING WORK SHEET}

Your Name:

Your Student Number:

This self-editing worksheet will enable you to proofread / evaluate your work and identify areas you need further help with.

As shown, the document includes 6 categories. We recommend that you focus on one of the categories below every time you read your work; however, you do not have to follow the menu in any particular order.

Process:

- Tick the box after checking each item in your work

- Add any comments / questions

- Rate your confidence for each section as shown
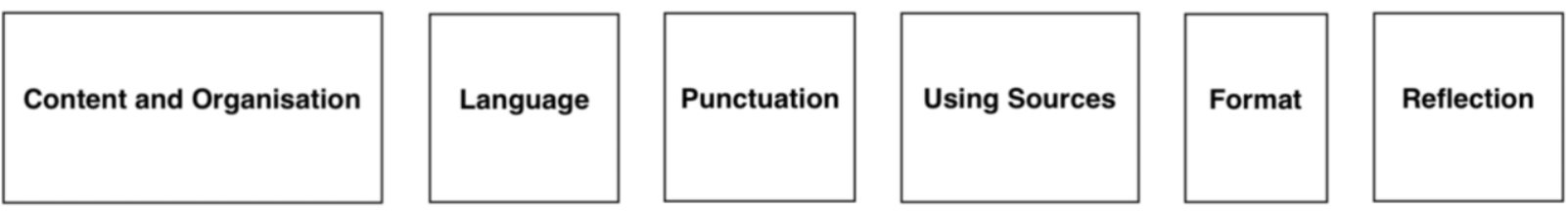

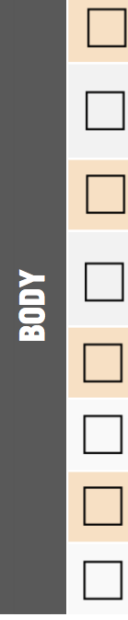

Each paragraph discusses only one main idea, and there are no sentences off the topic

If an idea is developed into two or more paragraphs (e.g. advantages and disadvantages of social networks), the paragraphs are linked with appropriate linking words (e.g. however, on the other hand)

Each paragraph starts with a topic sentence, which introduces the focus and the aim of the paragraph.

Ideas inside the paragraph expand on the topic sentence and support it with examples or evidence from other sources. View Example

Each paragraph has a cor

The paragraphs do not st A concluding emark could be one of

Cohesion within and betw - summary of the main ideas;

- summary of the main id

predicting, the future;
- transition to the following paragraph;

All the key points in the e - implication (i.e. consequences that

may happen in the future; suggestions

for wnat can be done in the future)
Overall, I feel:

Completely confident..

Partially confident...

Not at all confident...

...about the quality of my assignment's body

View Paragraph Example

This button provides additional explanations for the $5^{\text {th }}$ item in the list 


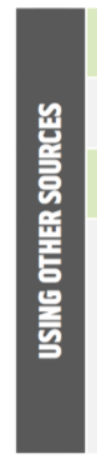

All quotes are explained, evaluated or commented on (to avoid descriptive writing).

Paraphrases and summaries are not too similar to the original text.

The author's voice is distinguished from that of other sources.

A clear sequence of the followings is found in most paragraphs (Synthesis, analysis and critique):

- The author's interpretation of what he/she has read

- Evidence to support the interpretations

- Exemplification to clarify the author's point

- Comparison of sources and, where appropriate, discussion of areas of consensus or contradictions

- A conclusion drawn from the discussion

\section{Comments or Questions}

Type your comments here...

\section{SECTION 2 - LANGUAGE}

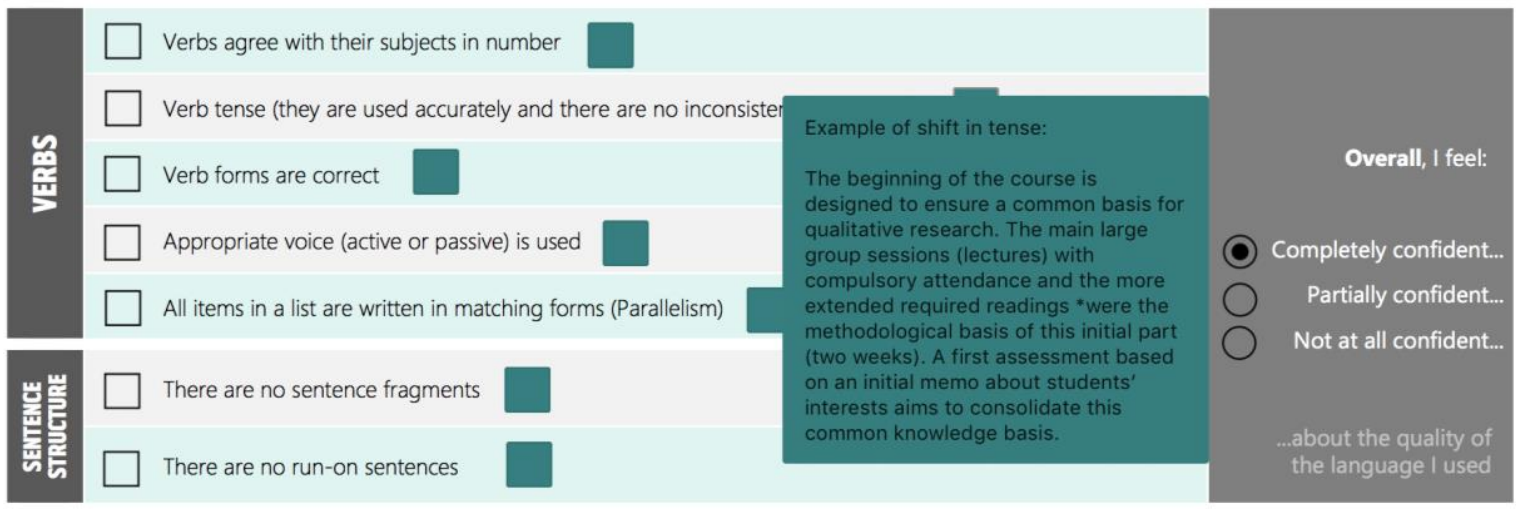

Comments or Questions

Type your comments here...

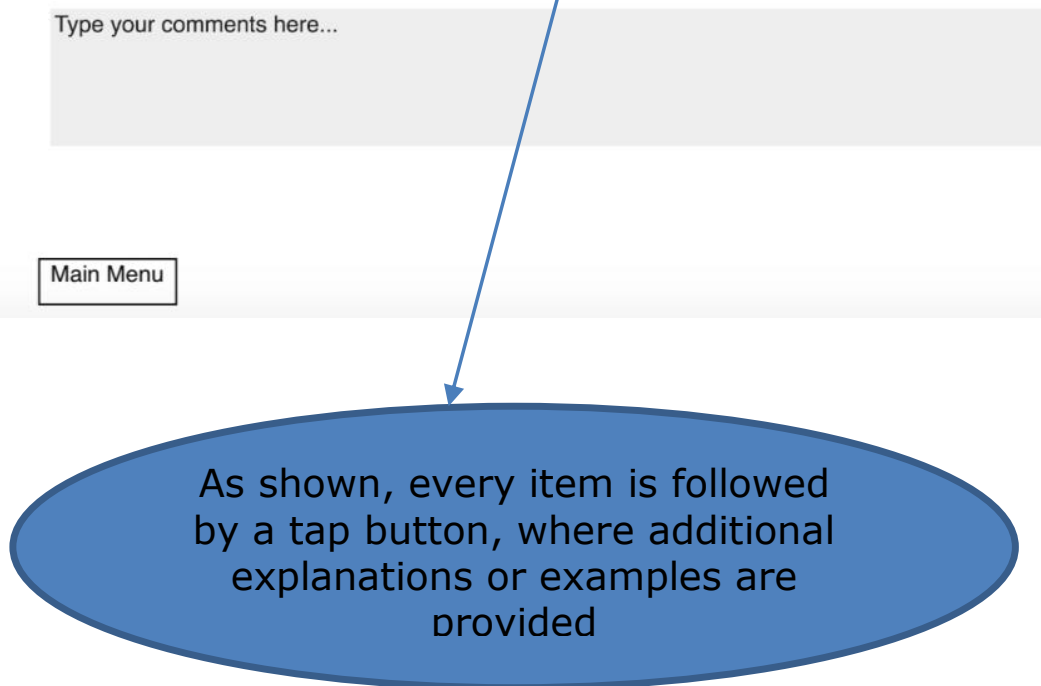




\section{SECTION 6 - REFLECTION}

\section{What part(s) of your paper are you most proud of and why?}

Type your answer here...

What areas of your writing will you concentrate on the most in your revision to improve? What is your major concern?

Type your answer here..

What errors or weaknesses did the worksheet help to identify?

Type your answer here...

On a scale of 1 to 5 , how useful did you find the worksheet?

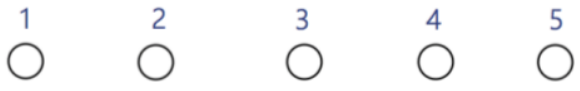

